\title{
The Effectiveness Of Internet-Based Supervision On The Covid 19 Pandemic Situation
}

\author{
Happy Fitria \\ Universitas PGRI Palembang \\ happyfitriamufly@univpgri-palembang.ac.id \\ Syarwani Ahmad \\ Universitas PGRI Palembang \\ syarwaniahmad@univpgri-palembang.ac.id \\ Dewi Novita \\ Universitas PGRI Palembang \\ dewinovita@univpgri-palembang.ac.id
}

\begin{abstract}
The background of this research starts from the current state and situation in the world. The coronavirus epidemic (Covid-19) was determined as a public health emergency that is troubling the world and the virus has now spread to various countries. Today's children and youth are global citizens, powerful drivers of change and members of future generations. Every crisis that occurs is an opportunity to help them learn, the most important is the protection of children and educational facilities. The impact of this situation has had a profound influence on the world of education. In the field of education, applying technology as an online educational tool that can be accessed by students. The progress and role of technology has been so prominent that the use of media and supervision has begun to be adjusted to progress. In the field of education supervision there are still obstacles and this can be overcome by utilizing an online-based supervision program. This research is a descriptive qualitative research with data collection techniques in the form of observation, documentation and interviews. This research was conducted at MAN 1 Musi Banyuasin. The results of this study indicate the supervisory competence of madrasah principals in monitoring the implementation of online learning in a covid-19 pandemic situation.
\end{abstract}

Keywords: Internet-based Supervision, Covid-19 Pandemic

Abstrak: Latar belakang penelitian ini dimulai dari keadaan dan situasi dunia saat ini.
Wabah virus corona (Covid-19) ditetapkan sebagai keadaan darurat kesehatan masyarakat yang
sedang meresabkan dunia dan kini virus tersebut telah menyebar ke berbagai negara. Anak-anak
dan remaja saat ini adalah warga dunia, pendorong perubahan yang kuat, dan anggota generasi
mendatang. Setiap krisis yang terjadi merupakan kesempatan untuk. membantu mereka belajar,
yang terpenting adalah perlindungan anak dan fasilitas pendidikan. Dampak dari situasi ini
telah memberikan pengaruh yang sangat besar terhadap dunia pendidikan. Di bidang pendidikan
menerapkan teknologi sebagai sarana pendidikan online yang dapat diakses oleh siswa. Kemajuan
dan peran teknologi sudah begitu menonjol sebingga penggunaan media dan pengawasan mulai
disesuaikan dengan kemajuannya. Dalam bidang supervisi pendidikan masih terdapat kendala
dan hal tersebut dapat diatasi dengan memanfaatkan program supervisi berbasis online. Penelitian
ini merupakan penelitian kualitatif deskriptif dengan teknik. pengumpulan data berupa observasi,
dokumentasi dan wawancara. Penelitian ini dilakukan di MAN 1 Musi Banyuasin. Hasil 
penelitian ini menunjukkan kompetensi supervisor kepala madrasah dalam memantau pelaksanaan pembelajaran online dalam situasi pandemi COVID-19.

Kata Kunci: Pengawasan Berbasis Internet, Pandemi Covid-19

\section{INTRODUCTION}

Education is a system that involves many components.Education has a role and strategic function in order to produce the children's creativity (Lian et al, 2018). These components are related to one another and affect mutually. Education is a planned effort to influence other people, both individuals, groups and communities to do what education practitioners expect (Murkatik et al, 2020). The components referred to according to Natawidjaja (2002) include: foundation, objectives, curriculum, teacher competence and professionalism, learning patterns, infrastructure, evaluation, financing and so on. Meanwhile, Salim (2004) identifies the following components of education: Madrasah principals, teachers, curriculum, educational facilities, education implementation systems and the social atmosphere of the Madrasah environment. All educational institutions in Indonesia have a duty and responsibility to build a generation that is potential and able to compete in the world market (Tobari et al, 2018).

Quality human resources can be realized with a good educational process and from quality educational institutions (Rahmadoni, 2018; Asvio et al, 2019). The quality of the school is essentially related to the supervision, the principal as the school leader of the teachers in the school. In the context of school autonomy, the principal has great authority in making policies at the school level, implementing and monitoring them, so that the school he leads has the ability to develop the potential that exists in the school. Leadership involves a process of social influence, in this case the deliberate influence carried out by someone on others to structure activities and relationships within a group or organization (Yuliani and Kristiawan, 2016).

The principal, as the person in charge of education at the school level, has the authority and power in developing various school programs, managing and supervising them. The principal must be able to practice innovations, be able to direct all members and the school as an educational organization into a change in mindset, improve vision and mission by utilizing the talents, skills and abilities of its members (Andriani et al, 2018). The principal has the flexibility to regulate all existing school resources, which can be utilized as much as possible for improving school quality and performance. Activities of direction, guidance and supervision carried out by the principal to teachers, staff and other employees are called supervision. Supervision is a coaching activity that is planned to assist teachers and other school employees in doing work effectively. 
The leadership of the principal is very supportive of achieving effective and efficient school management (Aprilana et al, 2016).

The principal's professional service to teachers is essential for improving the quality of the teaching and learning process. It can be said that the supervision of the principal affects the professional abilities of teachers and the professional abilities of teachers affect the quality of the teaching and learning process. The main mission of educational supervision is to provide services to teachers to develop the quality of learning, to facilitate teachers to teach effectively. According to Waspodo (2009) the potential for teacher resources needs to continue to grow and develop in order to carry out its function potentially. The principal faces greater challenges than the past in carrying out the duties and functions he plays on a daily basis (Komalasari et al, 2020).

At the beginning of 2020, the world was shocked by the outbreak of a new virus, namely a new type of coronavirus and the disease is called Coronavirus disease 2019 (Covid-19). It was found at the end of December 2019 that it was confirmed that there were 65 countries that had contracted this one virus (WHO data, March 1, 2020, PDPI, 2020). The coronavirus disease (Covid-19) outbreak is designated as a public health emergency that is troubling the world. Indeed, much remains unknown about the virus that causes Covid19, even though Covid-19 continues to spread, the public must take action to prevent further transmission and support government measures to control this disease, one of which is to work and learn from House.

Every crisis that occurs is an opportunity to help those who learn, the most important thing is protection for children and educational facilities. The impact of this situation has had a major impact on the world of education. In the field of education, applying technology as a means of online education that can be accessed by students. The progress and role of technology has become so prominent that the use of media and supervision has begun to be adjusted to the progress of the times. The challenge for supervisors is to expand opportunities for teachers by utilizing an integrated approach in order to improve professional competence (Zapenda, 2003).

In the field of supervision, in the Regulation of the Minister of Religion of the Republic of Indonesia number 58 of 2017 concerning madrasah heads, that one of the competences of madrasah heads is supervision. The spread of this virus has had a major impact on the world of education today. The government, with its regulations and the fatwa of the Indonesian Ulema Council, which must be carried out in an effort to break the chain of the spread of this virus, has made the world of education have to do this, namely by learning at home. In the field of education, the government has applied 
technology as a means of education that can be used today to educate the nation's life.

With advances in information technology today, the development of education in schools is increasingly changing and encouraging various change efforts. The education process in schools, especially our madrasah, has shown rapid development in the fields of curriculum, learning methodology, infrastructure and assessment, as well as in the field of education administration and education supervision. Overall, it can be said that the changes that occur are a renewal in the education system which involves all aspects or components that exist.

The teacher is still the main learning resource for students. Professional teachers have social responsibility manifested through teacher competence from the social environment and have effective interactive skills (Fitria et al, 2019). Teachers must find learning methods so that students participate actively in the learning process (Kristiawan, 2013). Many factors affect teacher performance, both external and internal factors (Maryati et al, 2020). Even though the development of technology today teachers can use technology as a medium of learning, especially in the current situation of the Covid-19 pandemic. The development of cellphone technology can be used for online learning. Besides that, as indicated by Kompasiana (2012) that Indonesia compared to other developing countries has a low quality of education, which is caused by seven factors, namely: learning only in textbooks, one-way teaching, lack of learning facilities, especially in the regions, binding regulations. , the culture of cheating, the open question method is not used, and the teacher does not instill a two-way discussion.

The policies taken by many countries, including Indonesia, by eliminating all educational activities, have made the government and related institutions have to present alternatives as an educational process for students and students who cannot carry out the educational process at educational institutions. Until now in Indonesia, several educational institutions have started to implement policies for teaching and learning activities from distance or online learning by utilizing the application of goggle classroom, zoom, e-learning. As a big nation, Indonesia must be able to go through all the existing problems. Indonesia must be ready with all possibilities, with the birth of technology created by the nation's children to provide educational services online or online. This is an effort so that students continue to study at home and educators are ready with scenarios including the application of working together to encourage online (online) or online learning for students (DetikManado, March 28, 2020). 
The Corona pandemic (COVID-19) is indeed a tough test for all nations on earth, testing the ability of all nations to be able to take lessons by continuing to strive and endeavor to find solutions to every problem that exists, including problems in the world of education. . The role of the head of the madrasah as a supervisor must still be carried out. According to Hambali (2016) the implementation of supervision is the duty of the head of madrasah to supervise teachers and school employees. Supervision activities vary. The implementation of supervision will still be carried out by the head of madrasah by taking several policies according to the current situation. Regarding the Covid-19 pandemic situation that is currently being experienced, including in the world of education, researchers want to conduct a study entitled The Effectiveness of Internetbased Supervision on the Covid-19 Pandemic Situation in MAN 1 Musi Banyuasin. The purpose of this research is to reveal the effectiveness of the implementation of supervision carried out online by the head of madrasah in the state of the Covid-19 pandemic so that the teaching and learning situation continues to run effectively.

Academic supervision provides an important contribution for teachers in mapping, implementing and evaluating the work program that has been determined. In order to improve the quality of education at every level of education, supervision is required. Supervision is supervision of academic activities in the form of teaching and learning processes, supervision of teachers in teaching, supervision of students who learn, and supervision of situations that cause it. Its activities are carried out by identifying learning weaknesses to be improved, then a follow-up is held in the form of improvements in the form of coaching. Coaching is a service to teachers in order to improve their performance. According to Donni and Somad (2014) coaching activities can be in the form of direct coaching or indirect coaching.

Currently, there are many forms of technology that can be used in conducting supervision activities, one of which is virtual supervision. Constraints on the lack of direct interaction between the supervisor and the teacher, the time and place for the implementation of supervision, which have been an obstacle, will be easily overcome with this system. Online-based supervision model is very effective and efficient. This is because a supervisor can monitor the activities of the fostered teachers, not necessarily in school, without limitation of time, place and distance. This model can provide more flexibility for teachers to convey input related to the quality of learning without having to meet face to face with the supervisor. Sabandi (2013) states that supervision moves from the form of inspection where authority is more dominated by supervisors, develops in the form of collaboration between supervisors and teachers together taking initiative and being responsible for 
improving the quality of learning, and fostering a learning culture in teachers to always improve their competence.

Nowadays, the role of technology can no longer be separated from education because information technology is very influential for education, namely in the field of time, cost and energy efficiency. The effect on time efficiency can be seen from the method of use and time of use. How to use it is enough to provide internet access and we can access it anywhere and anytime and it depends on the network access itself. Internet-based supervision is guidance in the form of guidance or guidance towards education and improving the quality of teaching and learning in an educational institution by implementing new systems that use modern technology such as computers, internet networks and so on, one example we can Look at the UNBK implementation in the last few years which has been based online. Nowadays, the role of the internet is very much needed because every agency is focused on developing information technology so that it can compete with other institutions that also make the process of education very simple and practical, for example by using e-learning so that it is very structured, organized and also very accurate. Taqizar (2018) says that with virtual-based supervision, a supervisor in one place can control many teachers in different schools. Collaboration between supervisors and teachers across different schools through online discussions is expected to be able to produce many studies in improving the quality of learning.

Initially epidemiological data showed $66 \%$ of patients were related to or exposed to a seafood market or live market in Wuhan, Hubei Province, China. Most Coronaviruses infect animals and circulate in animals. Coronavirus can only reproduce through its host. Covid-19 infection can cause mild, moderate and severe symptoms. The main clinical symptoms that appear are fever (temperature $>38^{\circ}$ ), cough and difficulty breathing. Furthermore, it can be accompanied by severe shortness of breath, fatigue, myalgia, gastrointestinal symptoms such as diarrhea and other respiratory symptoms. The outbreak of the Coronavirus is not a first-time event. In 2002, severe acute respiratory syndrome (SARS) was caused by SARS-Coronavirus (SARS-CoV) and Middle East Respiratory Syndrome (MERS) in 2012 caused by MERS-Coronavirus (MERS-CoV) with a total accumulation of around 10,000 cases (around 1000 cases of MERS and around 8000 SARS cases). The mortality due to SARS was around $10 \%$ while MERS was higher at around 40\% (PDPI, 2020).

Educational organizations around the world have had their school activities disrupted and their education rights have been threatened. President Joko Widodo appealed to work, study and worship from home during the Covid-19 pandemic. The government also decided to cancel the 2020 National 
Examination. To suppress the spread of Covid-19, since March 16, 2020 the government has decided that students learn from home. This policy is expected by the government to reduce the mobility of students and students so that they can reduce the spread of Covid-19. In practice, the teaching and learning process at home, students and teachers are assisted by online applications. Learning from home is a step that is considered effective in breaking the chain of spreading the virus. However, not a few parents and students who have trouble with this activity (Kompas.tv, April 5, 2020) are no exception for the head of the Madrasah too. For example, in carrying out its function as a supervisor that must be carried out.

\section{RESEARCH METHODS}

This research will use descriptive qualitative research. Descriptive research is carried out to describe the true thing about an unclear variable by taking the collected data and making systematic and accurate conclusion analysis. The research was conducted at MAN 1 Musi Banyuasin. Data obtained from observation techniques through e-learning, documentation and interviews delivered by respondents, namely the principal of the madrasah, teachers and students of MAN 1 Musi Banyuasin. In the case of the Covid-19 pandemic, the research was conducted online (via an internet application) as well as evidence that was considered important while within the scope of the study.

\section{RESULT AND DISCUSSION}

The quality of education is one of the educational problems that must be an important spotlight in improving the education system, especially with regard to the quality of learning. From the various conditions and potentials that exist, the effort that can be made to improve the quality is to develop student-oriented learning. Student-oriented learning can be done by building a learning system that allows students to have the ability to learn more interesting, interactive, and varied. Students must be able to have competencies that are useful for their future. Along with the development of technology and its supporting infrastructure, efforts to improve the quality of learning can be made through the use of this technology in a system known as online learning.

Online learning was first known because of the influence of the development of electronic-based learning introduced by the University of Illinois through a computer-based online learning system, which is a system that can facilitate students to learn more widely, more widely, and varies. Through the facilities provided by this system, students can study anytime and anywhere without being limited by distance, space and time. The learning material being studied is more varied, not only in verbal form, but also more varied such as visual, audio, and motion. 
If we look at the current situation, the Covid-19 pandemic situation requires us to stay at home, work from home and learn from home. The only alternative that can be done in the world of education is to use online learning. One of the ways to improve the quality of education is to continue to supervise education. If so far supervision has been carried out using conventional methods, then in the Covid-19 pandemic situation, supervision can still be carried out but with the virtual, namely online-based supervision, and this is also carried out by MAN 1 Musi Banyuasin.

Meanwhile, the quality of education cannot be separated from the existence of an ongoing educational and teaching process in educational institutions that requires systematic and planned coordination efforts. Hidayat and Machali (2012) state that efforts in this direction can be realized through the implementation of supervision. Supervision has an important role in improving the competence and professional abilities of teachers. Supervision is nothing but the application of democratic principles so that human potential can develop continuously both in the context of personal and collective life and everyone can participate in a community. The head of a madrasah has a supervisory function and one of the competencies that a madrasah head must have is supervision. So that the head of the madrasah is obliged to carry out educational supervision in any situation.

In this Covid-19 pandemic situation, the Head of Madrasah continues to carry out supervision of the teaching and learning process through online-based supervision. Based on the results of interviews with the Head of MAN 1 Musi Banyuasin regarding the implementation of online-based supervision related to online learning, that the Covid-19 pandemic situation that we are experiencing now means that face-to-face teaching and learning cannot be implemented and the teaching and learning process must be carried out but not directly but online, and this has been going on since the end of March 2020 based on a circular from the central government through the Ministry of Religion of South Sumatra Province and the Regent of Musi Banyuasin.

The Covid-19 pandemic situation has greatly affected the teaching and learning process, because what has been implemented face-to-face now has to be transferred to online media and this has encountered many obstacles. These constraints are the weaknesses of the online learning process, namely the absence of electronic devices such as cellular phones or computers, the difficulty of signals in remote areas not to mention the economic difficulties that cause no internet or pulse quota, but there are also advantages of this learning there is no space limitation and time, students and teachers will be smarter in using internet technology. Initially, the MAN 1 Musi Banyuasin teacher used Whattapps media, goggle classrooms, and finally madrasah e-learning as recommended by 
the central Ministry of Religion. Monitoring or monitoring of learning is still carried out through online media, namely by e-learning supervisors whose members consist of the Supervisor, Head of Madrasah and Deputy Head of Madrasah. While the supervision used is virtual-based supervision with the following stages: the curriculum representative makes a schedule for the implementation of supervision for the teacher, determines when the supervision will be carried out online, informs the teacher who will be supervised online, the principal will see the teacher's activity online so that The principal can provide an assessment to the teacher based on online supervision

The follow-up to the implementation of online-based supervision will be carried out by communicating directly online with the teacher concerned by providing signs about the implementation of this supervision, which must be improved for the learning process in the future to make it even better. Onlinebased supervision often experiences different obstacles from conventional supervision which is carried out face-to-face, so online-based supervision is not effective, but in any situation the teaching and learning process must be carried out in accordance with the targets and goals of national education. Based on the results of interviews with teachers and students related to online learning which has an impact on the implementation of supervision in the Covid-19 situation, the teacher initially experienced difficulties because it was something new to do online learning. Teachers must find learning media solutions that can be followed by students and not all students have electronic facilities in the form of androids or laptops, although this online learning makes technology literate for teachers and students but face-to-face learning is more fun and interesting because humans are social creatures who need interaction with fellow humans. To deal with online supervision, the teacher still has to prepare a Learning Implementation Plan, learning media in online form, teaching materials in the form of files and documentation in the form of online learning screenshots. Although online-based supervision is still implemented, online-based supervision is considered ineffective because there is no direct interaction with students or students or with the head of the madrasah as supervisor. Likewise, online learning is considered less effective even though online learning is very helpful in the current Covid-19 pandemic situation.

From the results of observations, there are many obstacles faced by teachers and students in online learning as well as in the implementation of online-based supervision, the most important thing is the frequent signal interference during learning, plus some students who cannot participate in learning because they are not internet quota or credit on the grounds that there is no money. From the results of interviews with students, it turned out that they preferred direct or face-to-face learning, because with direct learning, 
students could interact with the teacher and ask questions directly about material that they had not understood. Online-based supervision is very ineffective to implement, because there are often obstacles, especially from signal interference, but the implementation of supervision must be carried out even in the current situation of the Covid-19 pandemic.

\section{CONCLUSION}

From the results of the study it can be concluded that the principal as a supervisor still carries out supervision even though learning is carried out online by implementing online-based supervision, one of which is by using supervision or monitoring of teachers through the e-learning supervisor application carried out by MAN 1 Musi Banyuasin to All teachers are advised to remain active in carrying out the teaching and learning process even though it is carried out online and continue to monitor their students so that they continue to participate in active learning.

\section{ACKNOWLEDGEMENT}

The researcher thanks him for the support and guidance from all parties involved in this research, especially the LPPKM PGRI Palembang University, teachers and students as well as the Head of Madrasah MAN 1 Musi Banyuasin who has given permission to carry out this research.

\section{REFERENCES}

Andriani, S., Kesumawati, N., \& Kristiawan, M. (2018). The Influence of the Transformational Leadership and Work Motivation on Teachers Performance. International Journal of Scientific \& Technology Research, 7(7).

Aprilana, E. R., Kristiawan, M., \& Hafulyon, H. (2017). Kepemimpinan Kepala Madrasah dalam Mewujudkan Pembelajaran Efektif di Madrasah Ibtidaiyyah Rahmah El Yunusiyyah Diniyyah Puteri Padang Panjang [Leadership of Madrasah Principals in Realizing Effective Learning in Madrasah Ibtidaiyyah Rahmah El Yunusiyyah Diniyyah Puteri Padang Panjang]. ELEMENTARY: Islamic Teacher Journal, 4(1).

Asvio, N., Yamin, M., \& Risnita. (2019). Influence of Leadership Style, Emotional Intelligence and Job Satisfaction toward Organizational Commitment (Survey at SMA Muhammadiyah South Sumatera). International Journal of Scientific \& Technology Research 8 (8).

Darmiati, D., Kristiawan, M., \& Rohana, R. (2020). The Influence of School Leadership and Work Motivation toward Teacher's Discipline. Journal of Social Work and Science Education, 1(1), 32-44. Retrieved from https:// ejournal.karinosseff.org/index.php/jswse/article/view/8 
Detik Manado Redaktur. (2020). Dampak Pandemi Corona terhadap Dunia Pendidikan [The Impact of the Corona Pandemic on the World of Education]. https://detikmanado.com/dampak-pandemi-coronaterhadap-dunia-pendidikan/. Diakses 22 April 2020.

Donni, J. P.\& Somad, R. (2014). Manajemen Supervisi dan Kepemimpinan Kepala Sekolah [Supervision Management and Principal Leadership]. Bandung: Penerbit Alfabeta.

Fitria, H., Kristiawan, M., \& Rahmat, N. (2019). Upaya Meningkatkan Kompetensi Guru Melalui Pelatihan Penelitian Tindakan Kelas. ABDIMAS UNWAHAS, 4(1).

Hambali. (2015). Kinerja Guru dan Mutu Pendidikan [Teacher Performance and Education Quality]. Palembang: Noerfikri offset.

Hambali. (2016).Kepemimpinan Pendidikan Madrasah [Madrasah Educational Leadership]. Palembang: Noerfikri offset.

Hidayat, A. \& Marchali I. (2012). Pengelolaan Pendidikan [Education Management]. Yogyakarta: Kaukabu.

Imam Tobroni, S. R., Pelana, R., Sianipar, G., Guefara, R. L., \& Fathurrochman, I. (2020). Covid 19: Political Cooperation and Ritual Modification of Religious Worship Through Large-Scale Social Restrictions. Systematic Reviews in Pharmacy, 11(12), 644-648.

Lian, B., Kristiawan, M., \&Fitriya, R. (2018). Giving Creativity Room to Students throughthe FriendlySchool's Program. International Journal of Scientific\& Technology Research, 7(7).

Komalasari, K., Arafat, Y., \&Mulyadi, M. (2020). Principal's Management Competencies in Improving the Quality of Education. Journal of Social Work and Science Education, 1(2), 181-193. Retrieved from https:// ejournal.karinosseff.org/index.php/jswse/article/view/47

Kristiawan, M. (2013). The Implementation of Cooperative Learning in English Class of Favorite School of Secondary High School 5 Batusangkar, West Sumatera. International Journal of Educational Administration and Policy Studies, 5(6), 85-90.

Kristiawan, M., Jumeldi, A., Ahmad, S., \& Asvio, N. (2016). The Implementation of Affective Assessment for Islamic Education in High School 1 Pariangan. Research Journal of Social Sciences, 9(4), 18.

Kompasiana. (2012).Pendidikan di Indonesia bermutu rendah inilahpenyebabnya![This low quality education in Indonesia is the reason!]http://eduksi.kompasiana.com/2012/II/18/pendidikan-diindonesia-bermutu-rendah-inilah-penyebabnya-509196.html. Diakses 18 Nopember 2012. 
Maryati, E., Fitria, H., \&Rohana, R. (2020). The Influence of Principal's Leadership Style and Organizational Culture on Teacher's Performance. Journal of Social Work and Science Education, 1(2), 127139. Retrieved from https:// ejournal.karinosseff.org/index.php/jswse/article/view/38

Murkatik, K., Harapan, E., \& Wardiah, D. (2020). The Influence of Professional and Pedagogic Competence on Teacher's Performance. Journal of Social Work and Science Education, 1(1), 58-69. Retrieved from https:// ejournal.karinosseff.org/index.php/jswse/article/view/10

Natawidjaja. R., Sukamadinata. N.S., Ibrahim, R.,\&Djohar, A. (2002). [Rujukan Filsafat Teori dan Praktis Ilmu Pendidikan Reference to Philosophy Theory and Practical Science Education]. Bandung:Univeristas Pendidikan Indonesia Press.

Ngalim, P. (2000). Psikologi Pendidikan [Educational Psychology]. Bandung: PT. Remaja Rosdakarya.

Peraturan Menteri Agama Republik Indonesia Nomor 58 Tahun 2017 tentang Kepala Madrasah [Regulation of the Minister of Religion of the Republic of Indonesia Number 58 of 2017 concerning Madrasah Heads].

Rahmadoni, J. (2018). Isu Global Manajemen Pembiayaan Pendidikan di SD Indonesian Creative School Pekanbaru [Global Issues of Education Financing Management at SD Indonesian Creative School Pekanbaru]. Jurnal Manajemen, Kepemimpinan dan Supervisi Pendidikan 3(2), JuliDesember 2018.

Risdianto, E., Wachidi, Riyanto, Alexon, Fathurrochman, I., Kusen. (2021). Blended Learning Model Based on Massive Open Online Courses (MOOCs) Assisted by Augmented Reality (BMA) Model as the Electronic Learning Media in the Pandemic Covid-19. Al- Ishlah: Jurnal Pendidikan, 13 (1), 228-241. http://www.journal.staihubbulwathan.id/index.php/alishlah/issue/vie $\mathrm{w} / 30$

Sabandi, A. (2013).Supervisi Pendidikan untuk Pengembangan Profesionalitas Guru Berkelanjutan [Educational Supervision for Continuous Teacher Professional Development]. PEDAGOGI: Jurnal Ilmiah Ilmu Pendidikan Vol. XIII No.2http://ejournal.ump.ac.id/index.php/pedagogi.

Salim. (2004). Prospek Lembaga Pendidikan Islam[Prospects of Islamic Education Institutions].Makalah Ilmu Pengetahuan Agama. Univrsitas Sriwijaya, XV/4.

Sapa Indonesia. (2020). Sorotan: Dampak Corona ke Dunia Pendidikan[Highlight: The Impact of Corona on the World of 
Education]. www.kompas.tv/article/74608/sorotan-dampak-coronake-dunia-pendidikan. Diakses pada tanggal 22 April 2020.

Taqizar. (2018). Supervisi Berbasis IT,I/2[IT-Based Supervision, I / 2]. ISSN 2580-3433.

http://ejournal.kopertaiset.or.id/sasambo/index.php/at.tadbir.

Diakses pada tanggal 20 April 2020.

Tobari., Kristiawan, M. \& Asvio, N. (2018). The Strategy of Headmaster on Upgrading Educational Quality in Asean Economic Community (AEC) Era. International Journal of Scientific \& Technology Research 7 (4).

Waspodo. (2009). Efektifitas Pembelajaran[Learning Effectiveness]. Workshop Guru Pendidikan Agama Islam tingkat SMA se Sumatera Selatan. Palembang. Kanwil Kemenag Provinsi Sumatera Selatan.

Yuliana. (2020). Corona Virus Diseases (covic-19) sebuah tinjauan literatur[Corona Virus Diseases (Covic-19) a literature review]. 2/1 :p 187-192. ISSN 2656-0062.

Yuliani, T. \& Kristiawan, M. (2016). Peran Kepemimpinan Kepala Sekolah dalam Membina Kompetensi Sosial (Pelayanan Prima) Tenaga Administrasi Sekolah [The Role of Principal Leadership in Fostering Social Competence (Excellent Service) for School Administration Staff]. JMKSP Vol. 1, No. 2.

Zapenda, S. J. (2003). Instructional Supervision. New York: Eye on Education Library off Congress Cataloging in Publication data. 
32 Tadbir : Jurnal Studi Manajemen Pendidikan, Vol. 5, No. 1, 2021

This page belongs to the TADBIR : Jurnal Studi Manajemen Pendidikan

TADBIR : Jurnal Studi Manajemen Pendidikan Vol. 5, No.1, Mei 2021

IAIN Curup - Bengkulu | p-ISSN 2580-3581; e-ISSN 2580-5037 